\title{
YIELD AND YIELD STRUCTURE OF SPRING BARLEY (Hordeum vulgare L.) GROWN IN MONOCULTURE AFTER DIFFERENT STUBBLE CROPS
}

\author{
Dorota Gawęda \\ Department of Herbology and Plant Cultivation Techniques, \\ University of Life Sciences in Lublin, Akademicka 13, 20-950 Lublin, Poland, \\ e-mail: dorotagaweda@op.pl
}

Received: 29.11.2010

\begin{abstract}
A field experiment was conducted in the period 20062008 in the Uhrusk Experimental Farm belonging to the University of Life Sciences in Lublin. The experimental factor was the type of stubble crop ploughed in each year after harvest of spring barley: white mustard, lacy phacelia, winter rape, and a mixture of narrow-leaf lupin with field pea. In the experiment, successive spring barley crops were grown one after the other (in continuous monoculture). The aim of the experiment was to evaluate the effect of stubble crops used on the size and structure of barley yield. The three-year study showed an increasing trend in grain yield of spring barley grown after the mixture of legumes, lacy phacelia, and white mustard compared to its size in the treatment with no cover crop. Straw yield was significantly higher when barley was grown after the mixture of narrowleaf lupin with field pea than in the other treatments of the experiment. The type of ploughed-in stubble crop did not modify significantly plant height, ear length, and grain weight per ear. Growing the mixture of leguminous plants as a cover crop resulted in a significant increase in the density of ears per unit area in barley by an average of $14.7 \%$ relative to the treatment with winter rape. The experiment also showed the beneficial effect of the winter rape cover crop on 1000-grain weight of spring barley compared to that obtained in the treatments with white mustard and the mixture of legumes. All the cover crops caused an increase in the number of grains per ear of barley relative to that found in the control treatment. However, this increase was statistically proven only for the barley crops grown after lacy phacelia and the mixture of legumes.
\end{abstract}

Key words: stubble crop, yield, yield structure, monoculture spring barley.

\section{INTRODUCTION}

As a result of the high proportion of cereals in the crop structure, they are more and more frequently sown in stands after grain forecrops or grown in monoculture (Kw i atk ow ski, 2004). This contributes, among others, to gradual degradation of soil, since its macro- and micronutrient availability decreases, physical and biological properties deteriorate as well as weed infestation increases and the regrowth of troublesome species occurs (Thorup, 1994). A consequence of this is a frequent decrease in yields of cereals, including spring barley that belongs to plants particularly sensitive to improper crop sequencing.

One of the methods to reduce adverse changes in agroecosystems is stubble cropping ( $\mathrm{Andrze}$ j e w s k a , 1999). Growing stubble crops as green manure that is ploughed in, which improves the quality of the soil environment with relatively low outlays, is gaining special significance (D u e r, 1994; M a r s h a 11 et al. 2003).

The assumptions of sustainable farming propose that cover crops should be left in the form of mulch for the winter period - not ploughed in ( $\mathrm{S} z$ a f r a ń ski and Kulig, 2005). But some studies show that ploughing in post-harvest biomass has a more beneficial effect on yield of spring cereals than mixing the mulch with the soil directly before sowing ( $\mathrm{H}$ a $\mathrm{n}$ s e $\mathrm{n}$ et al. 2000).

The aim of the present study was to evaluate the effect of stubble crops ploughed in on yield and yield structure of spring barley grown in three-year continuous monoculture.

\section{MATERIALS AND METHODS}

This field experiment was conducted in the period 2006-2008 in the Uhrusk Experimental Farm belonging to the University of Life Sciences in Lublin.

In the experiment, spring barley (Hodeum vulgare L.) cv. Blask was grown in the stand after barley under continuous monoculture. The study factor was 
the type of stubble crop sown after harvest of spring barley: A - control treatment (with no cover crop), B - white mustard, C - lacy phacelia, D - winter rape, $\mathrm{E}-$ mixture of legumes (narrow-leaf lupin + field pea).

The experiment was established on medium heavy mixed rendzina soil. The soil showed an alkaline $\mathrm{pH}(\mathrm{pH}$ in $1 \mathrm{~mol} \mathrm{KCl}=7.7)$, average availability of phosphorus (65.0 mg $\mathrm{P} \mathrm{x} \mathrm{kg}{ }^{-1}$ of soil) and potassium (160.1 mg K x kg-1 of soil) as well as very low magnesium availability (20.1 mg Mg x kg-1 of soil). The humus content was at a level of $1.7 \%$, whereas the content of fines in the 0-30 cm layer was $35.0 \%$.

For all the study years, average air temperature (during the growing period of barley) was higher on average by $0.9^{\circ} \mathrm{C}$ than the long-term average (Table 1). In particular months of the period 2006-2008, air temperature was generally higher than long-term average temperatures. Lower temperature was only recorded in May 2008.

In 2006 and 2007 total rainfall during the growing period of barley (IV-VIII) much exceeded the long-term average by respectively 210.0 and $136.6 \mathrm{~mm}$ (Table 1). In 2008 total rainfall was lower by $19.6 \mathrm{~mm}$ than the long-term annual average. In spite of the lowest rainfall levels in the last year of the experiment, the highest barley yield was obtained. It is most probably attributable to a large amount of water at the time of sowing and during the initial growth of this plant (IV) when it has high water requirements. Higher rainfall than the long-term average was recorded in months IV, $\mathrm{V}$ and VII. April 2007 turned out to be the driest month of the three-year period. Lower rainfall than the longterm average was also recorded in April, June, and July 2006 as well as in June and August 2008. Taking into account particular months of the growing season during the duration of the experiment, the most abundant rainfall was recorded in August 2006 (Table 1).

The field experiment was set up in quadruplicate using the split-block design, in a stand after spring barley. The sown area of the plot was $35 \mathrm{~m}^{2}$, while the harvested area was $24 \mathrm{~m}^{2}$.

Stubble crops were sown each year in the second decade of August. Prior to sowing, single ploughing was done and a seedbed cultivator was used, consisting of a spring-tine harrow and a cage roller. The amount of seeds sown was as follows for particular plants: white mustard $15 \mathrm{~kg} \mathrm{x} \mathrm{ha}^{-1}$, lacy phacelia $10 \mathrm{~kg} \mathrm{x} \mathrm{ha}^{-1}$, winter rape $10 \mathrm{~kg} \mathrm{x} \mathrm{ha}^{-1}$, field pea and narrow-leaf lupin $90 \mathrm{~kg} \mathrm{x} \mathrm{ha}^{-1}$ of each. Every year the cover crops were ploughed in before winter to a depth of $25 \mathrm{~cm}$.

Pre-sowing tillage for spring barley cropping was done in a typical way (harrowing, seedbed cultivator: spring-tine harrow + cage roller). Before sowing the cereal crop, mineral fertilization was applied. Rates of mineral fertilizers were determined based on nutrient requirements of the plant and soil nutrient availability. NPK rates $\left(\mathrm{kg} \mathrm{x} \mathrm{ha}^{-1}\right)$ were as follows: $\mathrm{N}-50$ (ammonium nitrate $34.5 \%$ ), $\mathrm{P}-30$ (superphosphate $40 \%$ ), $\mathrm{K}-66$ (potassium salt $60 \%$ ).

Spring barley was sown each year in the first decade of April, at a rate of $140 \mathrm{~kg} \mathrm{x} \mathrm{ha}^{-1}$. Prior to sowing, seed dressing was applied, using a seed dresser made on the base of tiuram and carbendazim at a rate of $200 \mathrm{~g}$ per $100 \mathrm{~kg}$ of seeds.

In this experiment, only mechanical weed control was used, which involved harrowing at the 3-4-leaf stage (stage 13-14 in the BBCH scale). At stage 37, flag leaf just visible, still rolled, a fungicide containing the active substances propiconazole and fenpropidin was applied at a rate of $1.01 \mathrm{x} \mathrm{ha}^{-1}$. Spring barley was harvested at the fully ripe stage (the first decade of August). The yield traits (plant height, ear length, 1000grain weight, number of grains per ear, grain weight per ear) were determined based on a sample consisting of 30 ears randomly selected from each plot. Estimation of ear density of barley was made in sampling areas marked out by a frame with dimensions of $1 \mathrm{~m} \times 0.5 \mathrm{~m}$, in two randomly selected points of each plot.

Table 1.

Rainfall and temperature in months IV-VIII compared to long-term averages, 1964-2008, according to the Uhrusk Meteorological Station

\begin{tabular}{|c|c|c|c|c|c|c|}
\hline \multirow{3}{*}{ Year } & \multicolumn{6}{|c|}{ Months } \\
\hline & IV & $\mathrm{V}$ & VI & VII & VIII & IV-VIII \\
\hline & \multicolumn{5}{|c|}{ Rainfall (mm) } & Total \\
\hline 2006 & 32.0 & 98.8 & 35.2 & 47.6 & 327.2 & 540.8 \\
\hline 2007 & 24.4 & 98.8 & 96.0 & 156.8 & 91.4 & 467.4 \\
\hline 2008 & 51.0 & 71.7 & 36.4 & 113.0 & 39.1 & 311.2 \\
\hline \multirow[t]{2}{*}{ Averages 1964-2008 } & 39.6 & 63.8 & 71.3 & 86.8 & 69.3 & 330.8 \\
\hline & \multicolumn{5}{|c|}{ Temperature $\left({ }^{\circ} \mathrm{C}\right)$} & Mean \\
\hline 2006 & 8.8 & 13.5 & 17.0 & 21.5 & 17.6 & 15.7 \\
\hline 2007 & 8.2 & 15.1 & 18.4 & 19.2 & 18.6 & 15.9 \\
\hline 2008 & 9.1 & 12.9 & 17.4 & 18.3 & 18.6 & 15.3 \\
\hline Averages 1964-2008 & 7.7 & 13.5 & 16.5 & 18.2 & 17.4 & 14.7 \\
\hline
\end{tabular}




\section{RESULTS}

On average for the three-year study period, spring barley yield was not significantly dependent on the stubble crops ploughed in (Table 2). In the treatment with no cover crop and in the plot after winter rape, barley produced yield at an almost identical level. Compared to the control treatment, an increasing trend in grain yield was observed after ploughing in white mustard, lacy phacelia, and the mixture of legumes, with yield increases of $1.3,4.0$ and $7.7 \%$, respectively.

Statistically proven differences in spring barley yield were found in the second year of the study. Significantly higher yield was recorded in the barley crop grown after the mixture of leguminous plants relative to the other experimental treatments. The stand after winter rape and white mustard proved to be the least beneficial for productivity of this plant. After these cover crops, the decrease in barley yield was respectively 21.2 and $17.4 \%$ compared to that obtained in the treatment with the mixture of legumes.

The stubble crops significantly modified straw yield of spring barley in each year during the study period (Table 2). The highest value of the trait in question was found in the treatment with the ploughed-in mixture of narrow-leaf lupin with field pea. A proven decrease in straw yield, compared to that obtained in the barley crop grown after the mixture of legumes, averaged as follows: $14.8 \%$ after white mustard, $14.4 \%$ in the control treatment, $14.1 \%$ after winter rape, and $10.2 \%$ after lacy phacelia.

On average for the three-year study period, the stubble crops compared in this experiment did not modify significantly spring barley plant height (Table 3). Only a decreasing trend in the value of the trait in question was observed in all the treatments compared to that achieved in the crop grown after the mixture of narrow-leaf lupin with field pea. Statistically significant differences in barley plant height were only found in the third year of the study (2008). The lowest plants were then observed in the stand after ploughedin winter rape. Compared to this treatment, significantly higher plants were found in the crops grown after white mustard and the mixture of legumes, by 10.5 and $9.6 \%$, respectively. The stands after all the cover crops, except for winter rape, had a beneficial effect on the value of this trait compared to that found in the control treatment; however, this increase in plant height was not proved statistically.

On average for the three-year period, no significant effect was found of stubble crops on ear length of spring barley (Table 3). But there were proven differences in the second and third year of the experiment. In 2007 growing barley without cover cropping resulted in a significant reduction in ear length compared to that found in the treatments after all the cover crop plants, from $10.3 \%$ in the case of the plots with mustard and rape to $16.4 \%$ in the treatment with the leguminous plants. In 2008 the shortest ears were noted in the stand after the winter rape cover crop; they were significantly smaller compared to those found in the barley crop grown after white mustard and in the control treatment, by 12.6 and $11.6 \%$.

The type of stubble crop used had a significant influence on ear density of spring barley (Table 3 ). On average for the study period, the ploughing-in of the mixture of legumes had the most beneficial effect on the value of the trait under analysis. A significantly lower density of ears was obtained when the winter rape cover crop was used as an in-between crop in the cultivation of barley. The decrease in ear density relative to that found after the leguminous plants was 78.3 pcs. $\mathrm{x} \mathrm{m}^{-2}$, that is, by $12.9 \%$.

A similar influence of the stubble crops on ear density was found in the second (2007) and third year (2008) of monoculture cropping, whereas in the first year (2006) of barley cropping the differences were insignificant.

The introduction of stubble crops as a regenerating factor in spring barley monoculture cropping significantly differentiated thousand grain weight (Table 4). On average for the three-year period, a decrease in the value of this trait was found in all the other treatments of the experiment compared to the winter rape cover crop. Nonetheless, this decrease was statistically proven only with respect to the crops grown after white mustard and the mixture of lupin with pea. The difference in favour of the treatment with winter rape was $5.4 \%$ compared to white mustard and $4.7 \%$ relative to the mixture of legumes. Barley grain size also differed significantly in the years 2007 and 2008. In the second year of monoculture cropping (2007), the value of the trait in question was the highest in the stand after winter rape, while it was the lowest after the mixture of legumes and in the treatment with no cover crop. In the other treatments, 1000-grain weight was at a similar level that did not differ statistically. In 2008 1000-grain weight was highest in the control treatment with no cover crop. But a proven decrease in the value of this trait was found in the stand after the white mustard cover crop (by 9.3\%) and the mixture of legumes (by 6.0\%).

The stubble crops also modified significantly the number of grains per ear in spring barley (Table 4). On average for the three-year period, all the cover crops resulted in an increase in the value of this trait compared to that found in the control treatment. However, this increase was statistically proven only in the case of barley cropping after lacy phacelia and the mixture of legumes. The difference in favour of both these cover crops was $11.0 \%$. A significant influence of cover cro$\mathrm{ps}$ on the number of grains per ear was also found in the second and third year of spring barley monoculture. In 
2007 the lowest number of grains per ear was obtained in the treatment without cover crop. The stand with the ploughed-in legume biomass proved to be the most beneficial, and that with lacy phacelia was only slightly less beneficial. After these cover crops, the number of grains per ear was significantly higher compared to that found in the control treatment, by 2.6 and 2.4 pcs., respectively. In 2008, after ploughing in white mustard, a significant increase was recorded in the number of grains per ear in spring barley compared to that obtained in the other treatments; this increase was from $8.7 \%$ relative to the treatment with no cover crop up to $11.5 \%$ in the stand after the mixture of legumes.

Grain weight per ear of spring barley was at a similar level that did not differ statistically in all the treatments of the experiment (Table 4).

Table 2.

Grain yield and straw yield of spring barley depending on cover crop

\begin{tabular}{ccccccccc}
\hline & \multicolumn{4}{c}{ Grain yield $\left(\mathrm{t} \mathrm{x} \mathrm{ha}^{-1}\right)$} & \multicolumn{3}{c}{ Straw yield $\left(\mathrm{g} \mathrm{x} \mathrm{m}^{-2}\right)$} \\
\cline { 2 - 9 } Cover crop* & 2006 & 2007 & 2008 & Mean & 2006 & 2007 & 2008 & Mean \\
\hline A & 4.40 & 3.88 & 5.32 & 4.53 & 617.5 & 480.0 & 552.5 & 550.0 \\
B & 4.50 & 3.66 & 5.60 & 4.59 & 497.5 & 485.0 & 660.0 & 547.5 \\
C & 4.53 & 4.11 & 5.49 & 4.71 & 587.5 & 502.5 & 640.0 & 576.7 \\
D & 4.67 & 3.49 & 5.39 & 4.52 & 477.5 & 475.0 & 702.5 & 551.7 \\
E & 4.69 & 4.43 & 5.52 & 4.88 & 617.5 & 550.0 & 760.0 & 642.5 \\
\hline \multirow{2}{*}{ LSD0.05 } & n.s. & 0.324 & n.s. & n.s. & 138.40 & 60.96 & 64.20 & 50.63 \\
\hline
\end{tabular}

* - A: control treatment (no cover crop)

B: white mustard

C: lacy phacelia

D: winter rape

E: narrow-leaf lupin + field pea

n.s.: not significant

Table 3.

Some elements of the spring barley yield structure depending on cover crop

\begin{tabular}{ccccccccccccc}
\hline & \multicolumn{3}{c}{ Plant height (cm) } & \multicolumn{3}{c}{ Ear length (cm) } & \multicolumn{4}{c}{ Ear density (pcs. x m-2) } \\
\cline { 2 - 13 } Cover crop* & 2006 & 2007 & 2008 & Mean & 2006 & 2007 & 2008 & Mean & 2006 & 2007 & 2008 & Mean \\
\hline A & 37.9 & 63.0 & 69.7 & 56.9 & 6.7 & 6.1 & 8.6 & 7.1 & 664.0 & 567.5 & 500.0 & 577.2 \\
B & 36.9 & 60.4 & 73.5 & 56.9 & 6.4 & 6.8 & 8.7 & 7.3 & 549.0 & 551.0 & 541.5 & 547.2 \\
C & 37.0 & 58.9 & 70.0 & 55.3 & 7.3 & 6.9 & 8.2 & 7.5 & 574.5 & 553.5 & 544.0 & 557.3 \\
D & 39.3 & 65.0 & 66.5 & 56.9 & 7.0 & 6.8 & 7.6 & 7.1 & 535.0 & 529.0 & 529.0 & 531.0 \\
E & 40.9 & 61.2 & 72.9 & 58.3 & 7.0 & 7.3 & 8.1 & 7.5 & 659.5 & 593.5 & 575.0 & 609.3 \\
\hline \multirow{2}{*}{ LSD0.05 } & n.s. & n.s. & 5.00 & n.s. & n.s. & 0.53 & 0.90 & n.s. & n.s. & 54.91 & 48.28 & 68.37 \\
\hline
\end{tabular}

* Explanations as in Table 2

Table 4.

Some elements of the spring barley yield structure depending on cover crop

\begin{tabular}{|c|c|c|c|c|c|c|c|c|c|c|c|c|}
\hline \multirow{2}{*}{ Cover crop * } & \multicolumn{4}{|c|}{ 1000-grain weight (g) } & \multicolumn{4}{|c|}{ Number of grains per ear (pcs.) } & \multicolumn{4}{|c|}{ Grain weight per ear $(\mathrm{g})$} \\
\hline & 2006 & 2007 & 2008 & Mean & 2006 & 2007 & 2008 & Mean & 2006 & 2007 & 2008 & Mean \\
\hline A & 42.0 & 41.0 & 53.5 & 45.5 & 14.1 & 15.4 & 19.6 & 16.4 & 0.65 & 0.70 & 1.12 & 0.82 \\
\hline $\mathrm{B}$ & 41.6 & 42.6 & 48.5 & 44.2 & 15.6 & 16.1 & 21.3 & 17.7 & 0.73 & 0.70 & 1.09 & 0.84 \\
\hline $\mathrm{C}$ & 42.7 & 42.3 & 51.0 & 45.3 & 17.7 & 17.8 & 19.2 & 18.2 & 0.87 & 0.73 & 1.07 & 0.89 \\
\hline $\mathrm{D}$ & 43.2 & 44.0 & 52.5 & 46.6 & 15.8 & 15.5 & 19.4 & 16.9 & 0.84 & 0.73 & 1.03 & 0.87 \\
\hline $\mathrm{E}$ & 42.4 & 40.7 & 50.3 & 44.5 & 17.6 & 18.0 & 19.1 & 18.2 & 0.78 & 0.77 & 1.02 & 0.86 \\
\hline LSD0.05 & n.s. & 2.97 & 2.88 & 2.10 & n.s. & 0.91 & 1.50 & 1.68 & n.s. & n.s. & n.s. & n.s. \\
\hline
\end{tabular}

*-Explanations as in Table 2 


\section{DISCUSSION}

The study results show that, on average for the three-year study period, the ploughing-in of the stubble crops did not have a significant effect on yield of spring barley grown in monoculture. There was only observed an increasing trend in grain yield after most of the stubble crops. Likewise, in the studies of $\mathrm{Ku}$ s and Jończyk (2000) as well as Gawęda (2009 and 2010), cover cropping had a beneficial effect on yield of spring cereals. Nevertheless, the inclusion of cover crops in crop sequencing was not able to fully compensate for reductions in grain yield caused by growing cereal crops one after the other.

In the present experiment, the highest increase in barley grain yield was found in the barley crop grown after the mixture of legumes, relative to that obtained in the other treatments. These results are confirmed by the studies of Deryło (1997) in which it was demonstrated that the introduction of cover cropping by using a mixture of legumes as a factor counteracting soil fatigue in crop rotations with a large proportion of cereals increased grain yield of spring barley by $0.20 \mathrm{t}$ per ha.

The regenerating effect of stubble crops on grain yield of spring barley grown in three-year monoculture was shown by Kwiatkowski (2004). In this study, he found that grain yield in the control treatment with no cover crop was lower by 27.8 and $20.7 \%$, respectively, than that obtained under the conditions when mustard and a legume mixture were grown as an in-between crop. On the other hand, Skrzyc zy ński et al. (1992) proved that growing spring barley after different leguminous plants did not result in a significant difference in its yield. No regenerating effect of the white mustard cover crop on grain yield of spring barley was found in the present study. But other authors indicate the yield-increasing effect of this plant. An increase in grain yield of spring barley grown after a white mustard cover crop was found by the following researchers, among others: $\mathrm{Ku}$ ś et al. (1993), K o tw i c a et al. (1998), S i u t a (1998), and Jaskulski et al. (2000).

In the experiment under discussion, the stubble crops generally modified significantly ear density per $1 \mathrm{~m}^{2}, 1000$-grain weight, and number of grains per ear of spring barley. A significantly higher density of ears was found in the treatment with the ploughedin mixture of legumes than in the barley crop grown after winter rape. In the study of $\mathrm{Kw}$ i a t k ow s ki (2009), statistical analysis also proved the beneficial effect of a legume cover crop (vetch + field pea) on ear density of spring barley grown in monoculture; it was significantly higher that than obtained in the treatment with no cover crop. In the present study, an increasing trend was only observed in ear density of barley grown after the leguminous plants compared to that found in the control treatment. However, $\mathrm{Pu}$ a and $€ a b z$ a (2000) observed a beneficial effect of a white mustard cover crop on ear density of spring barley. In the experiment of these authors, the increase in ear density relative to its value in the control treatment was 32 ears per $1 \mathrm{~m}^{2}$.

On average for the three-year study period, the experiment under discussion proved a beneficial effect of the winter rape cover crop on 1000-grain weight compared to that found in the treatments with white mustard and the mixture of legumes. But this study did not find a significant effect of the cover crops under comparison relative to the treatment without the regenerating plant. Similarly, Kw i at kow ski (2009) did not prove the effect of the stubble crops on the increase in thousand grain weight (TGW). He only showed a small effect of a white mustard cover crop on the increase in TGW compared to its value in monoculture with no cover crop. On the other hand, D e r y ło (1994) as well as J a s ku ls ki et al. (2000) inform about the beneficial influence of a legume cover crop on thousand grain weight of spring barley, while $\mathrm{Pu} \nmid \mathrm{a}$ and $\mathrm{Eabza}$ (2000) report that white mustard ploughed in reduced grain size of spring barley by $5 \%$, on average, relative to its value in the control treatment with no cover crop.

The increase in the number of grains per ear of spring barley, shown in the present experiment, in the stand after the ploughed-in cover crops relative to the result obtained in the control treatment, also finds confirmation in the research of other authors. Among others, J a s kulski et al. (2000) found that an effect of pea, phacelia, and rye cover cropping was a significantly higher number of grains per ear of spring barley. Similarly, K w i a t k ow s ki (2009) showed an increase in the value of the trait in question by $6 \%$ in a barley crop grown after white mustard and legume cover crops compared to the value found in barley monoculture with no cover crop.

\section{CONCLUSIONS}

1. The stubble crops under comparison did not modify significantly grain yield of spring barley. An increasing trend in yield was only observed in the treatments with the mixture of legumes, lacy phacelia, and white mustard compared to that obtained when barley was grown with no cover crop.

2. The highest spring barley straw yield was found in the stand after the mixture of narrow-leaf lupin with field pea.

3. On average for the three-year study period, there was no significant effect of the ploughed-in stubble 
crops on plant height, ear length, and grain weight per ear of spring barley.

4. All the stubble crops caused an increase in the number of grains per ear of spring barley compared to that found in the control treatment (with no cover crop). This increase was statistically proven only in the case of barley grown after lacy phacelia and the mixture of legumes.

\section{REFERENCES}

Andrzejewska J., 1999. Międzyplony w zmianowaniach zbożowych. / Cover crops in cereal crop rotations. Post. Nauk Rol. 1: 19-31 (in Polish).

Deryło S ., 1994. Wpływ międzyplonów ścierniskowych na kształtowanie się struktury i jakość plonu pszenicy ozimej i jęczmienia jarego w płodozmianach zbożowych. / The effects of stubble crops on the structure and quality of winter wheat and spring barley yield in cereal crop rotation. Zesz. Nauk. ATR, Bydgoszcz, 35: 103-111 (in Polish).

D e r yło S ., 1997. Wpływ międzyplonu ścierniskowego i płodozmianów zbożowych na plonowanie i zachwaszczenie jęczmienia jarego. / The effects of stubble crops and cereal crop rotation on yield and weed infestation of spring barley. Ann. UMCS, Sect. E, 52(7): 69-76 (in Polish).

Duer I., 1994. Wpływ międzyplonu ścierniskowego na plonowanie i zachwaszczenie jęczmienia jarego. / The effects of stubble crops on yield and weed infestation of spring barley. Fragm. Agron. 4(44): 36-45 (in Polish).

Gawęda D., 2009. Wpływ międzyplonów ścierniskowych na plonowanie pszenicy jarej uprawianej w monokulturze. / The influence of stubble crops on yield of spring wheat grown in monoculture. Zesz. Probl. Post. Nauk Rol. 542(1): 147-156 (in Polish).

Gawęda D., 2010. Oddziaływanie międzyplonów ścierniskowych na plonowanie owsa uprawianego w monokulturze. / The effects of stubble crops on yield of oats grown in monoculture. Acta Agroph. 15(2): 247-255 (in Polish).

Hansen E.M., Kristensen K., Djurhuus J., 2000. Yield parameters as affected by introduction or discontinuation of catch crop use. Agron. J. 92: 909-914.

Jaskulski D., Tomalak S., Rudnicki F., 2000. Regeneracja stanowiska po pszenicy ozimej dla jęczmienia jarego przez rośliny międzyplonu ścierniskowego. / Stand regeneration after winter wheat for spring barley using stubble cropping. Zesz. Probl. Post. Nauk Rol. 470: 49-57 (in Polish).

Kotwica K., Jaskulski D., Tomalak S., 1998. Wpływ przyorywania masy roślinnej i zróżnicowanej uprawy roli na plon jęczmienia jarego wysiewanego po pszenicy ozimej. / The effect of ploughing-in of plant biomass and varying tillage on yield of spring barley sown after winter wheat. Pam. Puł. 112: 105-113 (in Polish).

Kuś J., Jończyk K., 2000. Regenerująca rola międzyplonów w zbożowych członach zmianowania. / The regenerating role of cover crops in cereal components of crop rotation. Zesz. Probl. Post. Nauk Rol. 470: 59-65 (in Polish).

Kuś J., Siuta A., Mróz A., Kamińska M., 1993. Możliwość kompensacji ujemnego wpływu stanowiska na plonowanie jęczmienia jarego. / The possibility of offsetting the adverse effect of the stand on yield of spring barley. Pam. Puł. 103: 133-143 (in Polish).

Kw i at kow sk i C ., 2004. Wpływ międzyplonu na plonowanie i zachwaszczenie jęczmienia jarego uprawianego w monokulturze. / The effect of cover crops on yield and weed infestation of spring barley cultivated in monoculture. Ann. UMCS, Sect. E, 59(2): 809-815 (in Polish).

Kwiatkowski C., 2009. Studia nad plonowaniem jęczmienia jarego nagoziarnistego i oplewionego w płodozmianie i monokulturze. / Studies on yield of naked and husked spring barley in crop rotation and monoculture. Rozpr. Nauk. UP Lublin, 336: 117 (in Polish).

Marshall E.J.P., Brown V.K., Boatman N.D., Lutman P.J.W., Squire G.R., Ward L.K., 2003. The role of weeds in supporting biological diversity within crop fields. Weed Res. 43: 77-89.

Puła J., Łabza T., 2000. Następcze działanie nawożenia organicznego na jęczmień jary. / The consequent effect of organic fertilization on spring barley. Zesz. Probl. Post. Nauk Rol. 470: 91-98 (in Polish).

Siuta A., 1998. Wpływ nawożenia słomą i uprawy międzyplonu na plonowanie jęczmienia jarego. / The influence of straw fertilization and cover cropping on yield of spring barley. Pam. Puł. 112: 179-185 (in Polish).

Skrzyczyński T., Boligłowa E., Starczewski J., 1992. Wartość przedplonowa roślin strączkowych dla jęczmienia jarego i pszenżyta ozimego. / Forecrop effects of leguminous plants for spring barley and winter triticale. Fragm. Agron. 4(36): 5-19 (in Polish).

Szafrański W., Kulig B ., 2005. Plonowanie pszenicy jarej uprawianej po międzyplonie w zależności od nawożenia azotem. / Yield of spring wheat cultivated after a cover crop depending on nitrogen fertilization. Fragm. Agron. 1(85): 574-584 (in Polish).

Thorup K., 1994. The effect of nitrogen catch crop species on the nitrogen nutrition of succeeding crops. Fert. Res. 37: $227-234$. 


\section{Plonowanie i struktura plonu jęczmienia jarego (Hordeum vulgare $\mathrm{L}$.) uprawianego w monokulturze po różnych międzyplonach ścierniskowych}

\section{Streszczenie}

Eksperyment polowy przeprowadzono w latach 2006-2008 w Gospodarstwie Doświadczalnym Uhrusk, należącym do Uniwersytetu Przyrodniczego w Lublinie. Czynnikiem badawczym był rodzaj międzyplonów ścierniskowych przyorywanych corocznie po zbiorze jęczmienia jarego: gorczyca biała, facelia błękitna, rzepak ozimy oraz mieszanka łubinu wąskolistnego z grochem siewnym pastewnym. W doświadczeniu uprawiano jęczmień jary w stanowisku po sobie (w narastającej monokulturze). Celem eksperymentu była ocena wpływu zastosowanych międzyplonów ścierniskowych na wielkość i strukturę plonu jęczmienia. W trzyletnich badaniach wykazano tendencję do wzrostu plonu ziarna jęczmienia jarego uprawianego po mieszance roślin strączkowych, facelii błękitnej i gorczycy białej w porównaniu do jego wielkości w obiekcie bez międzyplonu. Masa słomy jęczmienia była istotnie wyższa po mieszance łubinu wąskolistnego $\mathrm{z}$ grochem siewnym pastewnym niż w pozostałych obiektach eksperymentu. Rodzaj przyorywanych międzyplonów ścierniskowych nie modyfikował istotnie wysokości roślin, długości kłosa i masy ziaren z kłosa. Uprawa mieszanki strączkowych jako międzyplonu spowodowała istotny wzrost obsady kłosów jęczmienia na jednostce powierzchni średnio o 14,7\% względem obiektu z rzepakiem ozimym. Wykazano również korzystny wpływ międzyplonu z rzepaku ozimego na masę 1000 ziaren jęczmienia jarego w porównaniu do uzyskanej w obiektach z gorczycą białą i mieszanką roślin strączkowych. Wysiew wszystkich międzyplonów powodował zwiększenie liczby ziaren w kłosie jęczmienia w odniesieniu do stwierdzonego w obiekcie kontrolnym. Jednak tylko po facelii błękitnej i mieszance strączkowych był to wzrost udowodniony statystycznie. 